\title{
MOLECULAR ANALYSIS OF SURVIVAL MOTOR NEURON AND NEURONAL APOPTOSIS INHIBITORY PROTEIN GENES IN MACEDONIAN SPINAL MUSCULAR ATROPHY PATIENTS
}

\author{
Kocheva SA ${ }^{1,2}$, Vlaski-Jekic $\mathrm{S}^{3}$, Kuturec $\mathrm{M}^{2}$, Efremov GD ${ }^{1}$,
}

\begin{abstract}
*Corresponding Author: Professor Dr. Georgi D. Efremov, Macedonian Academy of Sciences and Arts, Research Centre for Genetic Engineering and Biotechnology, Aven Krste Misirkov 2, POB 428, 1000 Skopje, Republic of Macedonia; Tel: +389-2-3235411; Fax: +389-2-3115434; E-mail: gde@manu.edu
\end{abstract}

\begin{abstract}
Spinal muscular atrophy (SMA) is classified according to the age of onset and severity of the clinical manifestations into: acute (Werding-Hoffman disease or type I), intermediate (type II) and juvenile (Kugelberg-Wilander disease or type III) forms. All three SMAs have been linked to markers at $5 \mathrm{q} 11.2-\mathrm{q} 13.3$. Two candidate genes deleted in SMA patients are the survival motor neuron (SMN) gene and the neuronal apoptosis inhibitory protein (NAIP) gene. We have performed molecular analyses of these genes in 30 unrelated Macedonian families (17 with type I, eight with type II and five with type III forms of the disease). Deletions of exons 7 and 8 of the SMN gene were found in $76.6 \%$ $(23 / 30)$ of patients $(94.1 \%$ in type I, $87.5 \%$ in type II). Among these 23 families, 19 had both exons deleted, while four had deletions only of exon 7 . Deletions of exon 5 of the NAIP gene were found in $41.2 \%(7 / 17)$ patients with type I SMA and in

\footnotetext{
${ }^{1}$ Macedonian Academy of Sciences and Arts, Research Centre for Genetic Engineering and Biotechnology, 1000 Skopje, Republic of Macedonia 2 Pediatric Clinic, Faculty of Medicine, 1000 Skopje, Republic of Macedonia

${ }^{3}$ Neurology Clinic, Faculty of Medicine, 1000 Skopje, Republic of Macedonia
}

$12.5 \%(1 / 8)$ of patients with type II SMA. No deletions of the SMN gene were found in 30 parents and 30 normal controls. We found 2/30 (6.7\%) parents to be homozygous for the deletion of exon 5. Our data support the hypothesis that the telomeric SMN gene plays a major role in determining the clinical course of the disease, while the defects in the NAIP gene have only a modifying effect on the phenotype.

Key words: Spinal muscular atrophy (SMA); Survival motor neuron (SMN) gene; Neuronal apoptosis inhibitory protein (NAIP) gene

\section{INTRODUCTION}

Spinal muscular atrophy (SMA) is the second most common autosomal recessive disorder, with an overall incidence of about 1 in 6,000 to 10,000 live births and a carrier frequency of about $1 / 40$ [1]. The disease is characterized by degeneration of the $\alpha$-motor neurons of the anterior horns of the spinal cord, which leads to progressive symmetrical weakness and wasting in the proximal muscles. Three types of SMA have been distinguished on the basis of clinical severity and age of onset: type I (Warding-Hoffman disease) is the most severe form with clinical onset generally before the age of 6 months. Affected individuals cannot sit unaided and death usually occurs before the age of 2 years; type II is an intermediate form characterized by early onset, inability to walk 
and usually survive beyond the age of 10 years; type III (Kugelberg-Vilander disease), is the mild form being characterized by late age at onset and variable clinical severity. Affected individuals are able to walk independently and may have a normal life expectancy [2].

All three forms of SMA have been linked to markers at 5q11.2-q13.3 [3,4]. Deletional events within this region have been associated with SMA, and two candidate genes within this region identified: the survival motor neuron (SMN) and neuronal apoptosis inhibitory protein (NAIP) genes [5-9]. This region of the genome is inherently unstable, and contains with two almost identical copies of the SMN gene, one centromeric (SMNcen or cBCD541) and one telomeric (SMNtel) and multiple copies of pseudogenes of NAIP [10]. The two copies of the SMN gene differ in sequence by only five nucleotide changes along $20 \mathrm{~kb}$ and both are transcribed [9]. It has been reported that most SMA patients $(>95 \%)$ are homozygous for deletions of the SMN telomeric copy, but no specific mutations explaining the three SMA phenotypes have been found $[9,11]$. One full NAIP gene and several truncated copies are present in the SMA region. Specific exons of NAIP are deleted in SMA patients and also in $2 \%$ of unaffected carrier individuals. Deletions in the NAIP gene vary in frequency in different populations from 67.9 to $0 \%$ and appear to be higher in type I patients than in types II and III [7-18]. The NAIP gene shows similarity with baculoviral genes involved in inhibition of apoptosis in infected insect cells [7].Thus, loss of the NAIP gene is not sufficient to cause the disease. The NAIP gene is probably involved in modification of the severity of SMA. Recent studies have shown that a gene conversion event, in which the SMNtel is replaced by its centromeric counterpart (SMNcen), is a common mechanism in the genesis of mild SMA alleles, and an increased number of SMNcen genes may partially compensate for deficiency of SMNtel $[19,20]$.

We here present our data on the molecular analysis of the SMN and NAIP genes in patients with SMA from the Republic of Macedonia.

\section{MATERIALS AND METHODS}

Patients. A total of 30 unrelated SMA patients (17 with type I, eight with type II and five with type III form of the disease), 30 parents and 30 unrelated healthy individuals, were studied. Patients fulfilled the diagnostic criteria defined by the International SMA Consortium [21].

Molecular Analysis. Genomic DNA was extracted from peripheral blood lymphocytes following standard phenol/chlorophorm procedures [22]. The presence of deletions of exons 7 and 8 of the SMN gene were determined from polymerase chain reaction/restriction fragment length polymorphism (PCR/RFLP) analyses [23]. Polymerase chain reaction was carried out in a final volume of $25 \mu \mathrm{L}$ containing $100 \mathrm{ng}$ of genomic DNA, 20 pmoles of each primer, $200 \mathrm{mM}$ of each dNTP, $1.5 \mathrm{mM} \mathrm{MgCl}_{2}$ and $1 \mathrm{U}$ Taq DNA polymerase (Ampli Taq Gold; Applied BioSystems, Branchburg, NJ, USA). Sequences of the primers for amplification of SMN exon 7 (R111: 5'-AGA CTA TCA AAC TTA AAT TTC TGA TCA-3' and x-7Dra: 5'-CCT TCC TTC TTT TTG ATT TTG TTT-3') and SMN exon 8 (541C960: 5'-GTA ATA ACC AAA TGC AAT GTG AA-3' and 541C1120: 5'-CTA CAA CAC CCT TCT CAC AG-3') [23]. Samples were subjected to 30 cycles of amplification consisting of $1 \mathrm{~min}$. at $94^{\circ} \mathrm{C}, 1 \mathrm{~min}$. at $57^{\circ} \mathrm{C}$ and $1 \mathrm{~min}$. at $72^{\circ} \mathrm{C}$ and a final extension at $72^{\circ} \mathrm{C}$ for $10 \mathrm{~min}$. The PCR products of SMN exon 7 and SMN exon 8 were digested with $2 \mathrm{U}$ of restriction enzymes DraI and DdeI, respectively, at $37^{\circ} \mathrm{C}$ overnight. Digested products were run on $8 \%$ non denaturing acrylamide gel $(39: 1$ Acrylamide/BisAcrylamide) at $30 \mathrm{~mA}$ for 3 hours in TBE buffer and visualized under UV light after ethidium bromide staining. The PCR digestion products of exons 7 and 8 of the SMNtel gene and the copy gene can readily be distinguished since the copy gene contains a recognition site for the restriction enzyme (DraI/exon 7 and DdeI/exon 8) and that site is absent in the SMNtel (functional) gene. The SMN/exon 7/DraI digestion in healthy individuals, converged into two fragments to the SMNtel and SMNcen copy. The SMN/exon 8/DraI digestion gave three fragments: that with a higher molecular weight corresponding to SMNtel, and the rest corresponding to the SMNcen copy. Normal results were indicated by the presence of SMNtel and SMNcen exons 7 and 8 (Figure 1A and 1B). The restriction digest method does not differentiate between a true deletion and a gene conversion, but correctly determines the absence of SMNtel exons 7 and 8 from their normal genomic position. 

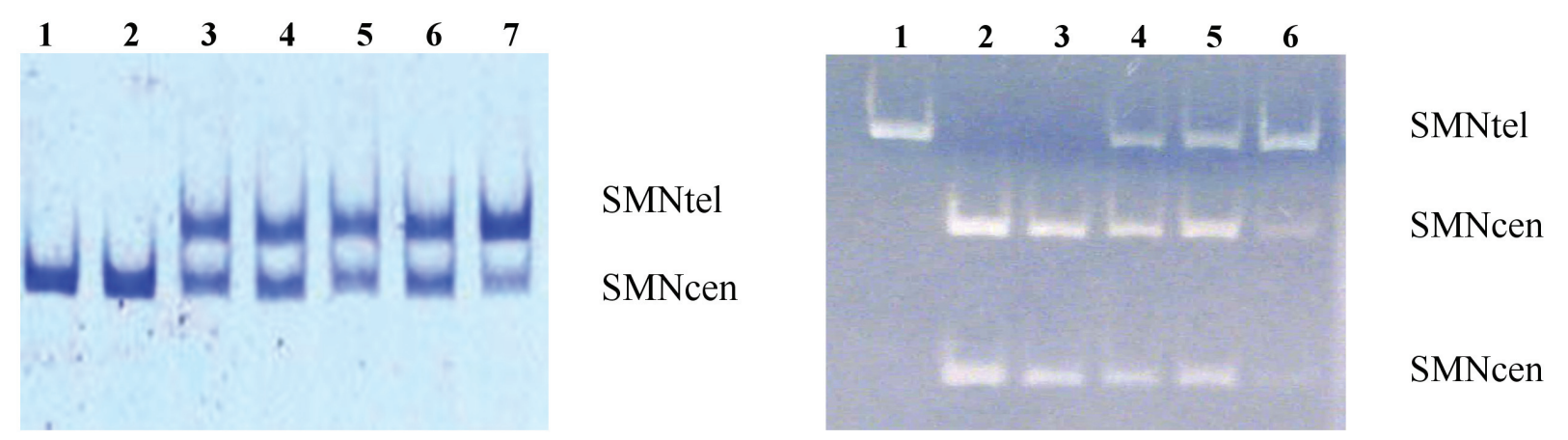

Figure 1. A) The PCR/RFLP analysis of exon 7. Lanes 1and 2: patients with homozygous deletion of SMNtel exon 7; lanes 3-7: normal pattern. B) The PCR/RFLP analysis of exon 8. Lane 1: undigested sample; lanes 2 and 3: patients with homozygous deletion of SMNtel exon 8; lanes 4-6: normal pattern.

Single-Strand Conformation Polymorphism Analyses of Survival Motor Neuron Exons 7 and 8. Single-strand conformation polymorphism (SSCP) analyses were carried out as described in (9). Genomic DNA (100-200 ng) was amplified using exon 7 R111 and 541C770 and exon 8 541C960 and 541C1120 specific oligonucleotide primers. A total of $10 \mu \mathrm{L}$ of PCR product was mixed with $10 \mu \mathrm{L} 95 \%$ formamide, $0,25 \%$ bromphenol blue and $0.25 \%$ xylene cyanol. The samples were denatured at $95^{\circ} \mathrm{C}$ for $5 \mathrm{~min}$. and loaded onto a $12 \%$ non denaturing acrylamide gel (39:1 Acrylamide/BisAcrylamide). The gels were run at $15 \mathrm{~W}$ for 16 hours at $16^{\circ} \mathrm{C}$ and visualized under UV light or after silver staining (Figure 2). The results were compared with those from DNA from healthy controls and from individuals with deletions confirmed by the restriction method.

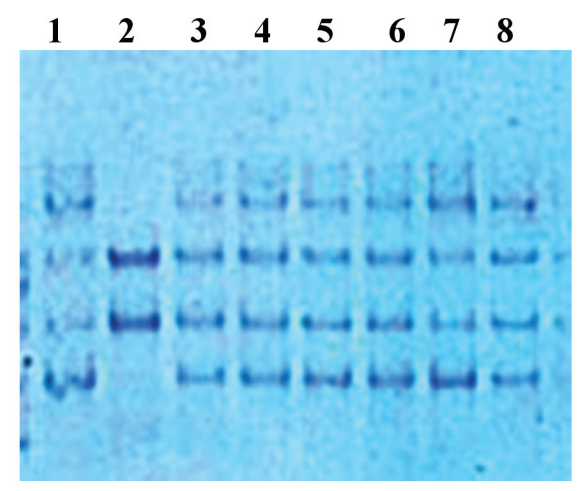

SMNtel

SMNcen

SMNtel

SMNcen

Figure 2. The SSCP analysis of exon 7 of the SMN gene. Lane 1: normal control; lane 2: patient with homozygous deletion of SMNtel copy; lanes 3-8: normal pattern.
Analysis of the Neuronal Apoptosis Inhibitory Protein Gene. The NAIP gene analysis was performed by multiplex PCR amplification of exons 5 and 13, using primers specific for exon 5 (1863: 5'-CTC TCA GCC TGC TCT TCA GAT-3' and 1864: 5'-AAA GCC TCT GAC GAG AGG ATC-3') and exon 13 (1258: 5'-ATG CTT GGA TCT CTA GAA TGG-3' and 1343: 5'-CCA GCT CCT AGA GAA AGA AGG A-3') as described in [7]. Exon 13 is present in both functional and pseu-dogene copies of NAIP and can therefore be used as a positive PCR control for exon 5 which is present only in the functional NAIP gene. The PCR was performed using the procedure described above, except that the annealing step was carried out for 1 min. at $60^{\circ} \mathrm{C}$. Samples were loaded onto a $2 \%$ agarose gel containing ethidium bromide, run for 1 hour at 80-100V and visualized under UV light (Figure 3).

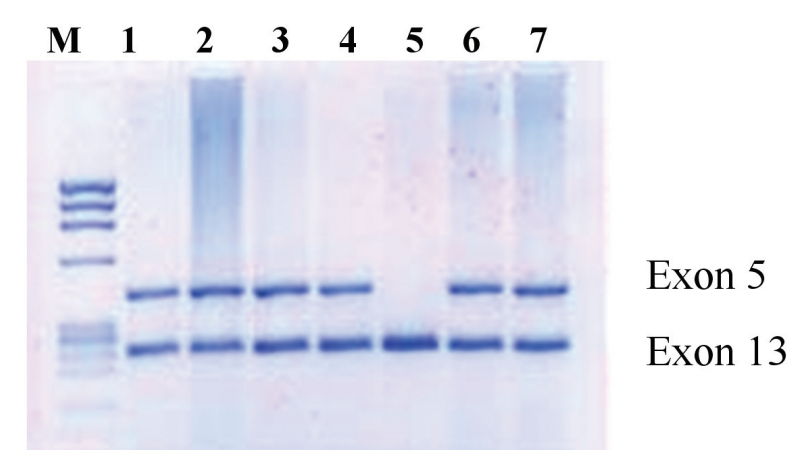

Figure 3. The PCR analysis of the NAIP gene. Lane 1: normal control; lanes 2-4, 6 and 7: normal pattern; lane 5: homozygous deletion of exon 5 . 


\section{RESULTS}

Analyses of Exons 7 and 8 of the Survival Motor Neuron Gene. Table 1 summarize the results of the screening of 30 SMA individuals. Seventy-seven percent of all the SMA patients $(94.0 \%$ of type I and $87.5 \%$ of type II) lacked the telomeric copy of the SMN gene. Of these, $83.0 \%(19 / 23)$ had deletions of both exons and $17.4 \%(4 / 23)$ had deletion of only exon 7 . The deletion was most common in patients with type I of the disease (94.1\%), less common in patients with type II $(87.5 \%)$. We did not detect a deletion of exons 7 and/or 8 in patients with type III.
(41.0\%) compared with type II (11.1\%). Genotype B, which represents smaller deletions (deletions of telomeric SMA exons 7 and 8), is predominantly found in type II SMA (50.0\%). Genotype C (deletion of exon 7) was found in three patients (two with type I and one with type II) and genotype D (no deletions of SMNtel exons 7 and 8 and NAIP) in one patient with type I, one with type II and five patients with type III. Genotype E, which represents deletions only in NAIP, was found in 2/30 (6.7\%) carriers. Genotype $\mathrm{G}$, which represents deletions in exon 7 of SMN and exon 5 of NAIP, was found in one patient with type II

Table 1. Deletion genotypes including SMN (exon 7 and 8) and NAIP (exon 5) genes

\begin{tabular}{|c|c|c|c|c|c|c|c|c|c|c|c|c|c|c|c|c|c|c|c|c|c|c|c|c|}
\hline Genotypes & & $\mathbf{A}$ & & & B & & & $\mathrm{C}$ & & & D & & & $\mathbf{E}$ & & & $\mathbf{F}$ & & & G & & & $\mathbf{H}$ & \\
\hline & 7 & 8 & 5 & 7 & 8 & 5 & 7 & 8 & 5 & 7 & 8 & 5 & 7 & 8 & 5 & 7 & 8 & 5 & 7 & 8 & 5 & 7 & 8 & 5 \\
\hline Exons & Del & Del & Del & Del & Del & $\mathbf{N}$ & Del & $\mathbf{N}$ & $\mathbf{N}$ & Del & $\mathbf{N}$ & $\mathbf{N}$ & $\mathbf{N}$ & $\mathbf{N}$ & $\mathbf{N}$ & $\mathbf{N}$ & Del & $\mathbf{N}$ & Del & $\mathbf{N}$ & Del & $\mathbf{N}$ & Del & Del \\
\hline $\begin{array}{l}\text { Phenotypes: } \\
\text { SMA type I }\end{array}$ & 41.2 & $2 \%(7$ & /17) & 41.2 & $2 \%(7$ & 17) & 11.7 & $\%(2$ & & 5.9 & $\%(1$ & 17) & & $0.0 \%$ & & & $0.0 \%$ & & & $0.0 \%$ & & & $0.0 \%$ & \\
\hline SMA type II & 11. & $1 \%($ & 1/8) & 50. & $.0 \%(4$ & & 12.5 & $5 \%($ & & 12. & $5 \%$ & & & $0.0 \%$ & & & $0.0 \%$ & & 12 . & $5 \%($ & & & $0.0 \%$ & \\
\hline SMA type III & 0.0 & $\% \%(0$ & & & $0.0 \%$ & & & $0.0 \%$ & & & $0.0^{\circ}$ & & & $0.0 \%$ & & & $0.0 \%$ & & & $0.0 \%$ & & & $0.0 \%$ & \\
\hline Parents & & $0.0 \%$ & & & $0.0 \%$ & & & $0.0^{\circ}$ & & 93.3 & $\%(2$ & $8 / 30)$ & 6.7 & $\%(2)$ & & & $0.0 \%$ & & & $0.0 \%$ & & & $0.0 \%$ & \\
\hline Controls & & $0.0 \%$ & & & $0.0 \%$ & & & $0.0 \%$ & & 100. & $0 \%$ & $0 / 30)$ & & $0.0 \%$ & & & $0.0 \%$ & & & $0.0 \%$ & & & $0.0 \%$ & \\
\hline
\end{tabular}

The pattern includes SMNtel exon 7, SMNtel exon 8, and NAIP exon 5. Del: homozygous deletion; N: without a homozygous deletion.

The centromeric copies of exons 7 and 8 were not affected in any of the patients, however, a deletion of one copy was found in one normal control. The SSCP analysis detected an aberrant fragment indicating a point mutation in exon 7 of the SMNtel gene in one type I patient.

Analyses of the Neuronal Apoptosis Inhibitory Protein Gene. Deletion of exon 5 of the NAIP gene was found in $41.2 \%(7 / 17)$ type I patients and in one type II patient (1/8). Only two of 30 parents $(6.7 \%)$ were found to be homozygous for the NAIP exon 5 deletion. No deletions of the NAIP exon 5 were found in 30 normal controls.

Correlation Analyses of Survival Motor Neuron and Neuronal Apoptosis Inhibitory Protein Gene Deletions. In order to correlate the extent of the deletion with clinical severity of disease, we have analyzed the deletion pattern of both genes. We have constructed genotypes of patients using the model proposed in [24]. The results are shown in Table 1. Genotype A, which represents a large deletion, including telomeric SMN exons 7 and 8 and also NAIP, has a higher incidence in type I SMA patients
SMA. Deletion only in SMNtel exon 8 (genotype F) and in SMNtel exon 8 and exon 5 of NAIP (genotype $\mathrm{H})$ was not found in our samples.

\section{DISCUSSION}

Our study of the molecular basis of SMA showed a frequency for SMN gene deletions in Macedonian patients of $77.0 \%$ (94.1\% in type I, $87.5 \%$ in type II). Deletions involving both exons 7 and $8(82.6 \%)$ was much more frequent than deletions of exon 7 only $(17.4 \%)$. Our data support the hypothesis that the telomeric SMN gene may play a major role in determin-ing the clinical severety of SMA [11-18,26-30]. Deletion of exon 5 of the NAIP gene was detected in $27.0 \%$ of SMA patients and in $6.7 \%$ parents. A higher frequency of deletions in the NAIP gene was found in SMA type I (41.2\%) than SMA type II $(11.1 \%)$ patients. Deletion in exon 5 of NAIP, which is specific for the functional NAIP gene, shows wide frequency variation $(0-67 \%)$ in different population studies [9-18]. The observation that deletions involving both SMN and NAIP genes are more frequently 
observed in SMA type I than SMA type II or SMA type III, suggests a correlation between the extent of the deletion and the severity of the phenotype. However, the fact that a great proportion of severely affected patients $(41.2 \%)$ presented no deletions in the NAIP gene supports the hypothesis that in addition to the extent of the deletion, other factors may regulate the severity of the clinical course. A relationship between the number of gene copies and the disease phenotype has been suggested $[19,20]$. Deletions of one or both of exon 5 of the NAIP gene is not sufficient to cause the disease. Patients with no detectable deletion in exons 7 and 8 of the SMN gene could be due to deletions or point mutations in the promotor or in exons under investiga-tion or could not be identified under these analytical conditions.

In summary, our data confirm the view that SMA is associated with a high frequency of deletions in the $5 \mathrm{q} 13$ chromosome region, and indicate that the more severe phenotype is associated with more extensive deletions. They also support the hypothesis that the telomeric SMN gene may play a major role in determining the clinical severity of SMA, while the NAIP gene has a modifying effect on the phenotype. Deletion screening in exons 7 and 8 of the SMNtel gene has become an important diagnostic tool in infantile SMA. DNA analysis is useful in confirming the clinical diagnosis of SMA and for prenatal prediction in SMA families.

\section{ACKNOWLEDGMENTS}

This study was supported by grants No. 4008662/98 from the Ministry of Science of the Republic of Macedonia and No. 11-513/1 from the science funds of the Macedonian Academy of Sciences and Arts (both to GDE).

\section{REFERENCES}

1. Pearn J. Classification of spinal muscular atrophies. Lancet 1980; 1(8174): 919-222.

2. Dubowitz, V. Muscle Disorders in Childhood. Philadelphia: W.B. Saunders Company. 1978; 146-90.

3. Brzustowick LM, Lehner T, Castilla LH, Penchasewicz GK, Wilhemsen KC, Daniels R, Davies KE, Leppert M, Ziter F, Wood D, Dubowitz V,Zerres K, Hausmanova-Petrisewicz I, Ott J, Munsat
TL, Gilliam TC. Genetic mapping of chronic childhood-onset spinal muscular atrophy to chromosome 5q11.2-13.3. Nature 1990; 344(6266): 540-541.

4. Melki J, Abdelhak S, Sheth P, Bachelot MF, Burlet P, Marcadet A, Aicardi J, Barois A, Carriere JP, Fardeau M, Fontan D, Ponsot G, Billete T, Angelini C, Ferriere G, Lanzi G, Ottolini A, Babton MC, Cohen D, Hanauer A, Clerget-Darpoux F, Lathrop M, Munich A, Frezal J. Gene for chronic spinal muscular atrophies maps to chromosome 5q. Nature 1990; 344(6268): 767-768.

5. Melki J, Lefebvre S, Burglen I, Burlet P, Clermont O, Millasseau P, Reboullet S, Benichou B, Zeviani $\mathrm{M}$, Le Paslier, Cohen D, Weissenbach J, Munnich A. De novo and inherited deletion on the $5 \mathrm{q} 13$ region in spinal muscular atrophies. Science 1994; 264(5164): 1474-1477.

6. Daniels RJ, Campbell I, Rodrigues NR, Francis MJ, Morrison KE, McLean M, MacKenzie A, Ignatius J, Dubowitz V, Davies KE. Genomic rearrangements in childhood spinal muscular atrophy linkage disequilib-rium with a null allele. J Med Genet 1995; 32(22): 93-96.

7. Roy M, Mahadevan MS, McLean M, Shutler G, Yeraghi Z, Farahani R, Baird S, Besner-Johnston A, Lefebvre S, Kang X, Salih M, Aubry H, Tamai K, Guan XP, Yoannou P, Crauford TO, Jong P, Surh L, Ikeda JE, Korneluk RG, MacKensie AE. The gene for neuronal apoptosis inhibitory protein is particularly deleted in individuals with spinal muscular atrophy. Cell 1995; 80(1): 167-178.

8. Thompson TG, DiDonato, CJ, Simard LR, Ingraham SE, Burghes A, AHM Crawford TO, Rochette C, Mendell JR, Wasmuth J. A novel cDNA detects homozygous micro deletions in greater than $50 \%$ of type I spinal muscular atrophy patient. Nat Genet 1995; 9(1):56-62.

9. Lefebvre S, Burglen I, Reboulet S, Clermont O, Burlet P, Viollet L, Benichou B, Cruaud C, Millasseau P, Zeviani M, Le Paslier D, Frezal J, Cohen D, Weissenbach J, Minnich A, Melki J. Identification and characterization of the spinal muscular atrophy determining gene. Cell 1995; 80(1): 155-165.

10. Morrisson KE, Qureshi SJ, Anderson S, Borrett JP, Theodosious A, Rodrigues N, Blake D, Nesbit A, Davies KE, Porteous DJ, Brookes AJ. Novel transcribed sequences represented in the complex genomic region 5q13. Boichim Biophys Acta 1996; 1308(2): 97-102. 
11. Rodrigues NR, Owen N, Talbot K, Patel S, Muntoni F, Ignatius J, Dubowitz V, Davies KE. Deletion in the survival motor neuron gene on $15 \mathrm{q} 13$ in autosomal recessive spinal muscular atrophy. Hum Mol Genet 1995; 4(4): 631-634.

12. Chang JM, Jong YJ, Huang J.M, Wang WS, Yang TY, Chang CP, Chen YJ, Lin SP. Molecular basis of spinal muscular atrophy in Chinese. Am J Hum Genet 1995; 57(6): 1503-1505.

13. Velasko E, Valero C, Valero A, Moreno F, Hernandes-Cilo C. Molecular analysis of the SMN and NAIP genes in Spanish spinal muscular atrophy (SMA) families and correlation between number of copes of cBCD541 and SMA phenotype. Hum Mol Genet 1996; 5(2): 257-263.

14. Brache C, Servidei S, Zappate S, Ricci E, Tonali P, Neri J. Genetic homogeneity between childhood-onset and adult onset autosomal recessive spinal muscular atrophy. Lancet 1995; 346(8977): 741-742.

15. Erdem H, Pehlivan S, Topalogly H, Yalnizoglu D, Akcoren Z. Deletions in the survival motor neuron gene in Turkish spinal muscular atrophy patients. J Inher Metab Dis 1996; 19(6): 724-728.

16. Wirth B, Hahnen E, Morgan K, DiDonato, CJ, Dadze A, Rudnik-Schoneborn S, Simard LR, Zerres $\mathrm{K}$, Burghes AH. Allelic association and deletion in autosomal recessive proximal spinal muscular atrophy: association of marker genotype with disease severity and candidate cDNA. Hum Mol Genet 1995; 4(8): 1273-1284.

17. Bili CH, Florentin L, Metaxotou C. Screening the SMN and NAIP genes in SMA families. Eur J Hum Genet 1996, 4(Suppl 5): 103.

18. Zatkova A, Hahnen E, Wirth B, Kadasi L. Analysis of the SMN and NAIP genes in Slovak muscular atrophy patients. Hum Hered 2000; 50(3): 171-174.

19. Campell I, PotterA, Ignatius J, Dubowitz V, Davies K. Genetic variation and gene conversion in spinal muscular atrophy: Implication for disease process and clinical phenotype. Am J Hum Genet 1997; 61(1): 40-50.

20. DiDonato CJ, Ingraham SE, Mendell JR, Prior TW, Lenard S, Moxley R, Florence J, Burhes AH. Deletion and conversion in spinal muscular atrophy patients: is there a relationship to severity? Ann Neurol 1997; 41(2): 230-237.
21. Munsat T, Davies KE. 1992. International SMA consortium meeting, 26-29 June, 1992, Bonn, Germany. Neuromusc Disord 2(5-6): 423-428.

22. Efremov GD, Dimovski AJ, Plaseska-Karanfilska D, Simjanovsa L, Sukarova E, Koceva S, Popovski Z. Laboratory Manual, 2nd ed. ICGEB Affiliated Center "Nucleic Acid Based Methods in Human and Veterinary Medicine," Skopje, Republic of Macedonia, 1998.

23. van der Steege G, Grootscholten PM,van der Viles P, Draaijers TG, Osinga J, Scheffer H, PCR based DNA test to confirm clinical diagnosis of autosomal recessive spinal muscular atrophy. Lancet 1995; 345(8955): 385-386.

24. Rodrigues NR, Owe N, Talbot K, Patel S, Muntoni F, Ignatius J, Dubowitz V, Davies KE. Gene deletions in spinal muscular atrophy. J Med Genet 1996; 33(2): 93-96.

25. Wang CH, Xu J, Carter TA, Ross BM, Dominski MK, Bellcross CA, Penchaszadeh GK, Munsat TL, Gilliam TC. Characterization of survival motor neuron (SMN) gene deletion in asymptomatic carriers of spinal muscular atrophy families. Hum Mol Genet 1996; 5(3): 359-365.

26. Brzustowicz LM, Wang CH, Matseoane D, Kleyn PW, Vitale E, Das K, Penchaszadeh GK, Mounsat TL, Huasmanowa-Petrisewicz I, Gilliam TC. Linkage disequilibrium and haplotype analysis among Polish familes with spinal muscular atrophy. Am J Hum Genet 1995; 56(1): 210-215.

27. Jordanova A, Stoyanova V, Uzunova M, Litvinenko I, Kremensky I. Deletion analysis of Bulgarian SMA families. Hum Mutat 1998; 12(1): 33-38.

28. Sertic J, Barisic N, Sostarko M, Bosnjak N, Culic V, Cvitanovic Ifrencak G, Brzovic Z, Stavlenic-Rukavina A. Deletions in the SMA and NAIP genes in patients with spinal muscular atrophy in Croatia. Coll Antropol 1997; 21(2): 487-492.

29. Aubry HL, Mackenzie AE, Surth LC. Delineat-ing the mutations in spinal muscular atrophy: improved molecular detection and genotype-phenotype correlation. Am J Hum Genet 1995; 57(Suppl): A234.

30. Kant JA, Rennert H, Joshi I,Wilson RB. Sensitivity of direct testing for SMN gene deletions in autosomal spinal muscular atrophy. Am J Hum Genet 1995; 57(Suppl): A331. 